In this situation, Israeli scientists find themselves fighting two battles at the same time. On the one hand, they are trying to convince their overseas colleagues that the common judgement of Israeli policies is too harsh. On the other hand, most of them of the need to change many of these policies.

Prominent scientists - including Professor Ephraim Urbach, president of the Israel Academy of Sciences and Humanities, and Professor Ephraim Katzir, former President of the State of Israel - played a prominent part in the successful attempt to force the appointment of a commission of judicial inquiry to probe the massacre of are trying to convince their fellow citizens

Palestinian refugees in Beirut. Many of these same scientists actively oppose the don't-give-back-an-inch views of the Begin government.

Even they however, are split over the question of a separate Palestinian state. Some think the emergence of such a state inevitable (or even desirable), while others would agree with what Shalheveth Freier said at the Pugwash meeting in Warsaw, where he declared: "If the general atmosphere in the Middle East continues to be uncompromisingly hostile to Israel, I suppose I should feel compelled to resist the creation of another hostile state. If, however, peace were to descend on this area, I believe that all honourable options would be open."

Nechemia Meyers

\section{Academic consultancy}

\section{Mass. General placates Hoechst \\ Washington \\ position is Hoechst's concern over its}

Massachusetts General Hospital (MGH) is going to unusual lengths to ensure that faculty consulting with outside firms does not conflict with the terms of its 10-year \$50-million agreement with Hoechst AG, the German chemical company.

In the case of one faculty member just appointed to the department funded by Hoechst, MGH is demanding that his consulting with other firms be on a non-confidential basis, a condition apparently not required of other $\mathrm{MGH}$ faculty.

The 1981 agreement between Hoechst and MGH represents the largest joint venture so far between industry and an academic institution. Hoechst agreed to provide the money for a new department of molecular biology in exchange for an exclusive licence to any patents that result from the department's research. The agreement also requires any faculty collaboration or consultation with for-profit firms to be cleared with Hoechst.

MGH has now apparently taken it upon itself to negotiate the particulars of consulting contracts that molecular biology faculty members have with outside firms to ensure that they are acceptable to Hoechst. In the case of Dr Brian Seed, the newlyappointed faculty member, $\mathrm{MGH}$ has engaged the services of a prominent Boston law firm, Ropes and Gray, to negotiate changes in his consulting arrangement with Genetics Institute. Genetics Institute, the spin-off from Harvard University's shortlived plan to form its own profit-making genetics engineering company, is negotiating through its own prominent Boston law firm, Hill and Dorr.

The MGH lawyers are demanding that since Seed is free to pass on information from his Hoechst-supported work at MGH to Genetics Institute, he should similarly be free to pass on to Hoechst any information gleaned through his consultations with Genetics Institute. Seed, who says he has heard nothing about the current status of the negotiations, says the basis of MGH's ability freely to exercise its patent rights under the agreement: "Hoechst is worried that as a result of my consulting for another company I might take up in my lab some work based on proprietary information". Thus Hoechst might end up supporting some research that it could not patent.

MGH officials deny that their actions reflect any special policy towards the department of molecular biology or Hoechst. "We want to make sure that their consulting activity is consistent with the hospital's policy', says Dr Ronald Lamont-Havers, deputy general director for research. "Any consultative agreement needs to be cleared with the hospital to ensure that there is no conflict of interest."

But Lamont-Havers did acknowledge that while the hospital has advised other faculty members that their consulting con tracts need to be changed, it has only actively negotiated those changes in the case of department of molecular biology faculty. And he appeared surprised to learn of the non-confidentiality requirement that MGH's own lawyers are demanding in Seed's case. "Usually, in our consulting agreements, we expect that they would receive proprietary information and would not be free to discuss proprietary information", he said.

Dr Howard Goodman, director of the department of molecular biology, denies that anyone in his department has been required to give up any consulting or that appointments have been made contingent upon modifications in an appointee's consulting contracts. And Seed seems confident that an accommodation will be reached in his case. "I doubt that my relationship with Genetics Institute will be severed", he says. But the lingering question is whether the conditions being demanded by MGH - and which Genetics Institute reportedly considers unacceptable - will make it impossible for at least some faculty consulting arrangements to continue.
US defence research

\section{Computer plan}

\section{Washington}

The US Department of Defense (DoD) is adding to its existing investment in computer research several new programmes designed to counter possible Japanese domination of the field. The budget for fiscal year 1984, which is now under negotiation behind closed doors, is likely to include hundreds of millions of additional dollars for special programmes in supercomputer research and software. DoD is already supporting research in Very Large Integrated Circuits, the technology of gallium arsenide as a replacement for silicon, and other computer-related programmes.

In a speech to a professional meeting in Orlando, Florida, Robert S. Cooper, director of the Defense Advanced Projects Research Agency (DARPA) announced that he would counter the Japanese computer effort with a research programme aimed at achieving the extraordinary speed of 10,000 million floating point operations per second by 1990 . Present "supercom-

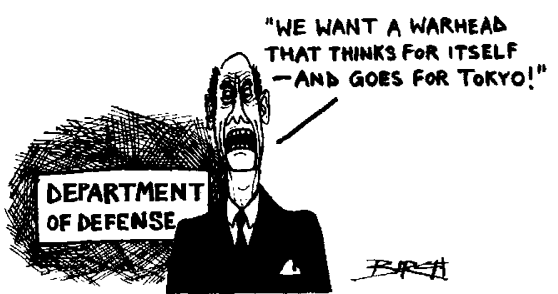

puters" such as the Cray III and Control Data's Cyber 205 attain speeds of 100 megaflops, while the Japanese programmes aims at achieving 1,000 megaflops. DARPA's programme is rumoured to have initial costs of $\$ 150$ million.

DARPA supports basic research and exploratory development for the directorate of Defense Research and Engineering and would not, therefore, be involved in applications. Possible defence applications include warhead delivery systems capable of "deciding" for themselves which targets to attack, and thus not dependent on vulnerable telemetry systems.

There is also to be a substantial new programme in the development of software to be managed by a new office to be established within the Defense Research and Engineering directorate. According to a report from the office of Dr Edith Martin, the deputy under-secretary at the Pentagon with responsibility for research and engineering, it is planned to spend an extra $\$ 30$ million on software development in the financial year beginning on 1 October 1983, to provide further funds in succeeding years and to establish a military software institute. It is estimated that between $\$ 5,000$ million and $\$ 6,000$ million worth of software is already "embedded" in defence systems, and that the amount will rise to $\$ 32,000$ million by 1990 .

Increased funds are also likely to be 
made available for the Very High Speed Integrated Circuits programme as well as for the research and development programme based on gallium arsenide, a material that offers faster semiconductor devices and may be more resistant to disturbances such as electromagnetic pulses.

The Pentagon's efforts to match the Japanese effort in advanced computers is mirrored by two initiatives by the computer industry. However, the plan of 15 computer companies under the leadership of the Control Data Corporation to invest between $\$ 50$ and $\$ 100$ million a year in software and hardware development has not yet become a reality even though the founders are confident that the US Department of Justice will decide that the proposed consortium, the Microelectronics and Computer Technology Corporation, does not violate anti-trust laws.

The non-profit Semiconductor Research Corporation, set up by 13 computer companies earlier this year, has however begun making grants to academic institutions considered to be centres of excellence in computer development. Last week, the corporation announced grants for developments in large-scale integrated circuit technology to Cornell University, the University of California at Berkeley and the Carnegie-Mellon University.

Deborah Shapley

\section{French win contract}

The British Central Electricity Generating Board (CEGB) has commissioned the design and safety study of the pressure vessel for the planned Sizewell B pressurized water reactor (PWR), Britain's first, from Framatome, the main constructor of the 40 or so French PWRs.

Thus Dr Walter Marshall, now director-general of CEGB, has proved true to his word. In March, when he was chairman of the United Kingdom Atomic Energy Authority, and head of the PWR task force that tidied up the Sizewell safety design, he was questioned about the problems that Framatome had had with cracks under the pressure vessel cladding. This would be just the time to buy from the French, said Marshall - because "they have been caught with their pants down". The problem was one of heat treatment, and has now been solved, Marshall believed, probably leaving Framatome with a better understanding of such vessels than other manufacturers.

From his position as head of CEGB, Marshall has now approved the offer of the design contract, worth $£ 213,000$, to Framatome. This will not be complete until May 1983, after the January 1983 Sizewell inquiry, but - according to Framatome sources - a report amounting to "the bulk" of the study will be ready in time for the inquiry.

Robert Walgate

MRC annual report

\section{Universities stand to gain}

Like publishers, heads of research councils are usually a gloomy bunch when it comes to public statements on the financial position of their organizations. But at last week's launch of the annual report of the UK Medical Research Council (MRC), the council's secretary, Sir James Gowans, was remarkably cheerful about MRC finances and even offered a helping hand to the universities.

The hand-out, which all told could amount to 1 per cent of the annual budget of $\mathrm{MRC}$, is offered to university research teams, in particular those already within the system of dual support by MRC and university, whose cutting edge has been dulled by diminished support from the university. To restore their competitiveness until such time as university finances are again healthy, MRC is offering to convert such teams into MRC Groups, providing them with up to $£ 50,000$ per annum.

The scheme, advertised earlier this year, has attracted some twenty applicants, almost all of them already substantially financed by the MRC. To ensure that the money is awarded to cases of genuine hardship, the vice-chancellor of the university has to make the application and to promise that he is not trying to free resources which will be redeployed into unrelated activities. Although no decisions have yet been made it is likely that the support awarded to MRC groups will cover such items as radiochemicals, an electron microscopist, an animal-house technician or even a departmental secretary.

MRC seems willing to spend up to $£ 1$ million a year in this way. Where will the money come from? Nowhere in particular, according to Sir James Gowans. Nevertheless, two main sources seem likely.

The first would be the $£ 1$ million that would be saved were MRC to withdraw its support of the European Molecular Biology Laboratory (EMBL) in Heidelberg. The suspicion that it might do so arises from an instruction from the Advisory Board for the Research Councils telling MRC to review its participation in EMBL. Asked why he thought the review was called for, Sir James Gowans would say only that the question should be addressed to the Advisory Board - of which he is a member.

Alternatively, it might be surmised, MRC could support its proposed groups by spending less on project and programme grants to university teams. According to the annual report, "the growing volume of applications for support . . . suggests . . . that some good work will continue to go unfunded" but in fact no really good project ever seems to fail to be supported.

Looking ahead, Sir James Gowans drew attention to the review next year of the fiveyear agreement between MRC and the biotechnology company Celltech. The agree- ment runs until 1985 and Sir James thinks "it is going all right". He also mentioned the National Institute of Medical Research (NIMR) which this year will consume about $£ 9$ million of the $£ 106$ million MRC budget. Sir James expects Dr D.A. Rees, formerly principal scientist at Unilever's Colworth laboratory but director of NIMR since 1 October, to increase the links between NIMR and industry and to open facilities at NIMR to university researchers. In addition, the structure of NIMR will be reorganized during 1983

Peter Newmark

\section{Rostow a "dove" \\ Washington}

Part of the reason for the apparent stalemate of the Geneva arms control negotiations seems to be a dispute between a group of conservative senators and Mr Eugene V. Rostow, director of the Arms Control and Disarmament Agency (ACDA). The dispute may come to a head as soon as 29 November when a group in the Senate led by Senator Jesse Helms (Republican, North Carolina) will try to send Rostow a warning that he is too doveish towards the Soviet Union - and put the President on notice as well.

The Helms group first signalled its discontent in March, when the Senate Foreign Relations Committee considered the nomination of two longterm ACDA officials kept on by the Administration at Rostow's urging. Helms complained that Robert Grey, nominated as deputy director, and Norman Terrill, nominated as assistant director for nuclear weapons policy, were hold-overs from the Carter Administration and too doveish.

Since then, confirmation of the two nominees has been held up in the Senate because of Helms's objections. When Congress reconvenes on 29 November for about a month, there will be a move to bring the nominations to the floor of the Senate, which is possible only if Helms withdraws his objection. There is a rumour that only the Grey nomination will be called up. The Helms faction, which would prefer General Edward Rowney to have Rostow's job, seems to have calculated that postponing Terrill's confirmation as acting assistant director will continue to embarrass Rostow and, in particular, prevent him from taking a decisive position on arms control.

If the two nominations are not confirmed by the time Congress finally disbands, the whole nomination process will have to begin all over again in the new Congress next February.

Deborah Shapley 